\title{
Insight \\ Insight on Invasions and Resilience Derived from Spatiotemporal Discontinuities of Biomass at Local and Regional Scales
}

\author{
David G. Angeler $^{1}{ }^{1}$ Craig R. Allen $^{2,3}$, and Richard K. Johnson $^{1}$
}

\begin{abstract}
Understanding the social and ecological consequences of species invasions is complicated by nonlinearities in processes, and differences in process and structure as scale is changed. Here we use discontinuity analyses to investigate nonlinear patterns in the distribution of biomass of an invasive nuisance species that could indicate scale-specific organization. We analyze biomass patterns in the flagellate Gonyostomum semen (Raphidophyta) in 75 boreal lakes during an 11-year period (1997-2007). With simulations using a unimodal null model and cluster analysis, we identified regional groupings of lakes based on their biomass patterns. We evaluated the variability of membership of individual lakes in regional biomass groups. Temporal trends in local and regional discontinuity patterns were analyzed using regressions and correlations with environmental variables that characterize nutrient conditions, acidity status, temperature variability, and water clarity. Regionally, there was a significant increase in the number of biomass groups over time, indicative of an increased number of scales at which algal biomass organizes across lakes. This increased complexity correlated with the invasion history of $G$. semen and broad-scale environmental change (recovery from acidification). Locally, no consistent patterns of lake membership to regional biomass groups were observed, and correlations with environmental variables were lake specific. The increased complexity of regional biomass patterns suggests that processes that act within or between scales reinforce the presence of G. semen and its potential to develop high-biomass blooms in boreal lakes. Emergent regional patterns combined with locally stochastic dynamics suggest a bleak future for managing G. semen, and more generally why invasive species can be ecologically successful.
\end{abstract}

Key Words: algal blooms, alternative states, biological invasions, boreal lakes, complex adaptive systems, discontinuities, landscape ecology, panarchy, resilience

\section{INTRODUCTION}

Species invasions are one of the foremost environmental challenges of the new millennium, threatening biodiversity and jeopardizing the provision of ecosystem goods and services (Millennium Ecosystem Assessment 2005). A case in point is algal blooms, which can arise from ecosystem perturbations, e.g., nutrient enrichment, in lakes that negatively affect structure, function, and services (Pickhardt et al. 2002, Rondel et al. 2008). In boreal lakes, blooms of the raphidophycean flagellate Gonyostomum semen (Ehrenberg) Diesing have negative impacts on the recreational services of lakes, causing allergic skin reactions in swimmers and maintenance costs in water treatment plants (Cronberg et al. 1988, Hongve et al. 1988).

A range expansion of Gonyostomum and an increased incidence of bloom formation across boreal lakes have been documented in recent decades (Trigal et al. 2011). Broad-scale anthropogenic drivers such as global warming and recovery from anthropogenic acidification seem to favor $G$. semen (Eloranta and Räike 1995, Findlay et al. 2005, Rengefors et al. 2008), facilitating bloom events during which the phytoplankton community can be dominated for extended periods by this alga, comprising as much as $98 \%$ of phytoplankton biomass (Le Cohu et al. 1989). Because of its negative effects on lake ecosystem services (Cronberg et al.
1988, Hongve et al. 1988), the Swedish Environmental Protection Agency treats this alga as a noxious species but currently lacks science-based information necessary for effective management. Because algal blooms will be of increasing management concern in a warmer future (Rabalais et al. 2009, Vilhena et al. 2010), water resource managers require information for local and regional conservation planning to mitigate negative ecological and socioeconomic impacts that can derive from the future range expansion of $G$. semen and other invasive species.

To optimize conservation planning, metrics are needed that are simple, yet ecologically integrative. Biomass is a taxonfree ecological attribute that integrates ecologically relevant ecosystem conditions and processes, i.e., resources, production, competition, mortality, mass, and energy flow, and the biomass of target populations can also be costeffectively measured. Because population explosions of species are intimately related to their biomass structure, the determination of local and regional biomass structure of invasive species can be useful for assessing the factors that influence, or are affected by, nuisance species (e.g., Pattison et al. 1998, MacDougall and Turkington 2005). This, in turn, can provide management information about their spatiotemporal dynamics in ecosystems and landscapes (Richardson 1996, Müllerová et al. 2005).

${ }^{1}$ Swedish University of Agricultural Sciences, Department of Aquatic Sciences and Assessment, ${ }^{2}$ U.S. Geological Survey, Nebraska Cooperative Fish and Wildlife Research Unit, ${ }^{3}$ School of Natural Resources, University of Nebraska, Lincoln 
The ecological literature is dominated by assumptions that attributes of ecological systems are distributed continuously, and that such distributions are unimodal (Allen et al. 2006). However, many of the factors that influence the organization of ecological systems vary across distinct spatial and temporal scales (Gunderson and Holling 2002, Angeler et al. 2011). Changes of system characteristics from one scale to the next are not well described by linear relationships, rather they often change abruptly with the scale of analysis, highlighting the existence of discontinuous structure in ecosystems and other complex adaptive systems (Allen and Holling 2008, Garmestani et al. 2009). When systems pass a critical threshold and shift into a new regime, attractor domains are changed and a system reorganizes around new sets of structural and functional processes (Allen et al. 2005). The alternative stable state concept exemplifies such sudden, often catastrophic regime shifts. For example, a shallow lake can exist in a clearwater state dominated by aquatic vegetation, but with excessive nutrient enrichment a sudden transformation, i.e., regime shift, into a turbid state dominated by phytoplankton can occur (Scheffer 2004).

Allen et al. (2005) proposed discontinuity analyses to quantify and compare sudden changes in ecological patterns. The ability to measure and quantify discontinuities provides a relative measure of the resilience of complex systems, because insight may be gained regarding the number of dominant scales of process and structure that are present in a system (Allen et al. 2005, Stow et al. 2007). Furthermore, the distribution of processes, structure, and function within a system affects system resilience, and the quantification of discontinuities and aggregations, and the distribution of function within and across aggregations, i.e., across scales, provides insight into relative resilience (Peterson et al. 1998, Allen et al. 2005).

In this paper we assess the discontinuities of biomass patterns of G. semen during an 11-year period between 1997 and 2007 in 75 Swedish lakes. We assess if biomass patterns exist, and if so quantify the patterns present by determining discontinuities in biomass of G. semen (Allen et al. 1999). We determine biomass discontinuity patterns at local (lake) and regional scales, expecting that the spatiotemporal imprints of ecological processes mediating these patterns differ between these scales (Allen et al. 2006). At the regional scale, we expect that the organization of biomass groups closely tracks the invasion history of $G$. semen across the landscape. We hypothesize that with an increasing occurrence of G. semen in Swedish lakes, biomass patterns will become more variable and complex, leading to an increased number of discontinuities in biomass patterns at the landscape scale. Because $G$. semen invasion seem to be associated with broadscale environmental change, this increased complexity should be associated with regional environmental drivers, thereby reflecting slower regional-scale processes (Allen et al. 2006).
From a management perspective, temporally increasing regional complexity in the number of discontinuities, or scales, suggests that redundant structures emerge at the landscape scale that can reinforce the existence of nuisance species (Allen and Holling 2010). The difficulties in identifying and manipulating the sets of environmental and biotic variables that contribute to this cross-scale reinforcement may increase with this increasing complexity, and ultimately complicate regional conservation planning. From a more specific invasion point of view, regionally increasing complexity in biomass organization could provide a more detailed understanding of the ecological success of invasive species that may not be evident from traditional analyses based on assumptions that ecological attributes are continuous and unimodal.

At the local scale, we hypothesize that discontinuities arise from the interannual variability of algal biomass, and by extension the magnitude of blooms observed in individual lakes (Angeler et al. 2010). We evaluate local discontinuity patterns by examining the temporal variability of membership of individual lakes to regional biomass groupings over time. We correlate the temporal patterns in group membership with raw biomass data to evaluate whether temporal discontinuities in local biomass structure arise from the ecological factors that individually or collectively affect biomass dynamics rather than as a result of our approach to deduce local from regional patterns. G. semen biomass within individual lakes inconsistently correlates with environmental variables (Angeler et al. 2010). This suggests that the control of biomass dynamics of $G$. semen can have an underlying stochastic component that makes predictions of bloom dynamics using environmental variables difficult. This stochasticity, combined with lake-idiosyncratic associations between environmental variables and G. semen biomass (Angeler et al. 2010), may be due to faster processes acting at local scales (Allen et al. 2006).

\section{METHODS}

\section{Study area}

In the late 1980s, Sweden initiated a long-term monitoring program for lakes (Johnson 1999). Seventy-five lakes, distributed across Sweden and suitable for reconstructing the spatiotemporal patterns of biomass variability of G. semen, could be selected from the database (Appendix 1). The selected data cover a 10-year study period (1997-2007), which allows assessment of changes in biomass structure resulting from invasions over a relatively short (decadal) time span. The lakes are environmentally heterogeneous, spanning gradients in water clarity, acidification status, trophic status, and lake size. Comprehensive information regarding the Swedish monitoring program is available online (http:/www.slu.se/va tten-miljo/). 


\section{Sampling}

Surface water samples $(0.5 \mathrm{~m})$ were collected once during summer, usually August, at a midlake station in each lake. Water was collected with a Plexiglas sampler and kept cool during transport to the laboratory. Samples were analyzed for physicochemical variables, including those indicative of acidity, (e.g., $\mathrm{pH}$, alkalinity, $\mathrm{SO}_{4}{ }^{2-}$ concentration); nutrients, (e.g., Total $\mathrm{P}, \mathrm{NH}_{4}-\mathrm{N}$ ); and water clarity, i.e., Secchi depth, water color, total organic carbon (TOC). All physicochemical analyses were done at the Department of Aquatic Sciences and Assessment following international (ISO) or European (EN) standards when available (Wilander et al. 2003).

Phytoplankton was sampled at a midlake site in August of each year by taking a water sample from the epilimnion using a Plexiglas tube sampler (diameter $=3 \mathrm{~cm}$ ). Water samples were preserved with Lugol solution, and phytoplankton counts were made using an inverted light microscope and a modified Utermöhl technique (Olrik et al. 1989). Taxa were identified to the finest taxonomic unit, usually species, and speciesspecific biovolume measures were calculated using geometric formulas. Only biovolume data of $G$. semen are used in our analysis, and this is referred to as biomass unless otherwise noted.

Our analyses are restricted to a single summer sample per year because there was no higher seasonal sampling resolution in our data sets. Although a higher intra-annual sampling resolution would allow for the detection of finer scale temporal patterns of biomass group dynamics, it would not necessarily improve the long-term signal derived from our single sample analyses collected when boreal lakes have the highest biological activity and $G$. semen bloom impacts in lakes are most severe. Furthermore, because most lakes are relatively small and wind-protected, blooms do not show strong spatial heterogeneity in these lakes (Karin Johansson, Swedish University of Agricultural Sciences, personal observation). Covering summer periods in our study is therefore ecologically and socioeconomically relevant.

\section{Statistical analyses}

Determination of patterns of biomass discontinuities

Prior to discontinuity analyses we prepared a matrix for each year in which we listed the ascending log-transformed biomass data from each lake. Only lakes in which G. semen occurred were used for analyses, so the number of biomass values from lakes used for analysis varied between 20 and 31 over the study period (Fig. 1). Discontinuity analyses were then carried out separately for each year to identify discontinuities in the ordered biomass values.

Stow et al. (2007) have shown that several methods can detect discontinuities in data sets, but that because the results can vary in detail between methods, several methods should be used in parallel in an adaptive inference framework. We used
Fig. 1. Distribution of Gonyostomum semen biomass in different lake aggregation groups between 1997 and 2007 resolved by cluster analysis and simulations analysis; $\mathrm{n}$ indicates the number of lakes with biomass values $>0$ used in the yearly analyses. The vertical dotted lines indicate discontinuities between successive groups of lakes with similar biomass characteristics. Lakes that fall within these biomass groups are shown by the black dots.

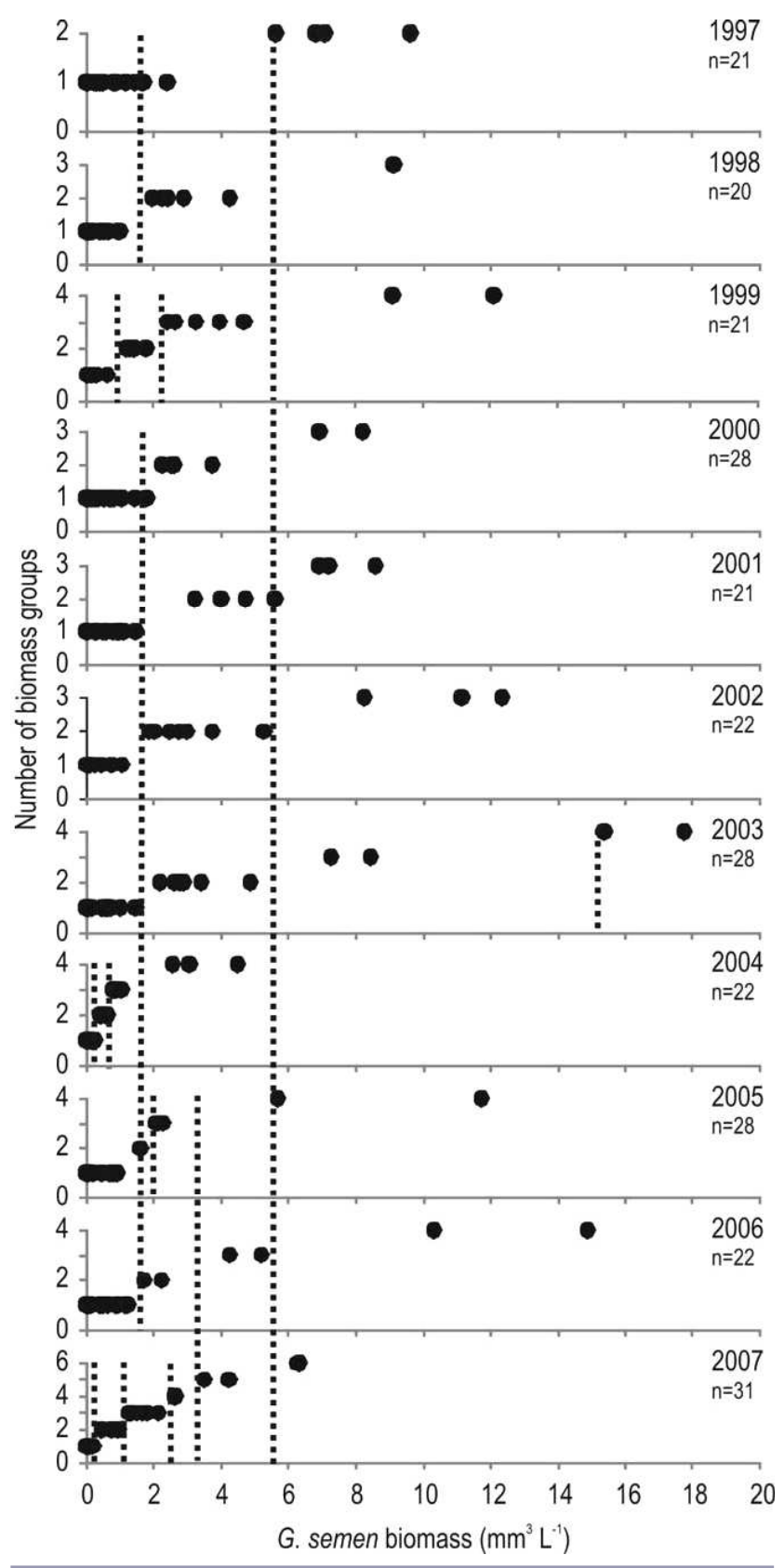


two approaches for detecting discontinuities in regional $G$. semen biomass patterns; that is, identifying groups of lakes with similar biomass characteristics that are separated by discontinuities. First, we used simulations that compared observed data with a null distribution established by estimating a continuous unimodal kernel distribution of the logtransformed data (Silverman 1981). Significance of discontinuities in the data were determined by calculating the probability of finding discontinuities at least as extreme as the observed discontinuities by comparing observed values with the output of 1000 simulations from the null set (Restrepo et al. 1997). We believe that the application of a null model is the best method for determining discontinuities, but we also confirmed our results with a hierarchical cluster analysis (SAS Institute 1999) that determines clusters, and thus discontinuities, in the data based upon variance reduction. The final determination of discontinuities was based on both methods, which in most cases converged. In this study, we refer to discontinuities in the data set as an area between successive groups of lakes with similar biomass characteristics that significantly exceeds the discontinuities generated by the continuous null distribution, whereas biomass group refers to a grouping of two or more lakes with biomass characteristics not exceeding the expectation of the null distribution (Allen et al. 1999).

\section{Landscape-scale discontinuity patterns}

Linear regression analyses were used to test for significant trends in the detection of $G$. semen in the study lakes; that is, whether the number of $G$. semen-free lakes decreases over time, and to test the conjecture that the number of biomass groups increases significantly over the study period (Hypothesis 1). We used Kendall tau correlation analyses (Kendall 1938), a nonparametric test of concordance that measures agreement between two rankings, to evaluate the associations between temporal changes in the regional occurrence of $G$. semen and biomass groups, and correlations of occurrence and biomass group patterns with environmental variables indicative of climatic conditions (water temperature), acidity status $(\mathrm{pH}$, alkalinity, sulfate concentrations), nutrient status (total phosphorus, $\mathrm{PO}_{4}$, total nitrogen, $\mathrm{NH}_{4}-\mathrm{N}, \mathrm{NO}_{2}+\mathrm{NO}_{3}-\mathrm{N}$ ), ion content (electrical conductivity), and water clarity (Secchi disc transparency, water color [absorbance], total organic carbon). We used mean values of these variables, averaged from the 75 lakes, as regional abiotic correlates of $G$. semen distributions and biomass group trends.

\section{Local discontinuity patterns}

Data from the discontinuity analyses were used to determine the membership of individual lakes to regional biomass groups over the study period. Because patterns of local discontinuity are derived from the regional analysis, we confirmed through correlation analysis that local lake membership to regional biomass groups is associated with the raw biovolume data of
G. semen. Raw biovolume has been measured at the local scale of lakes, and therefore allows testing the hypothesis that discontinuous organization arises from the interannual variability in magnitudes of development of this alga in the lakes (Hypothesis 2). We used the same sets of environmental variables as for the landscape analysis to test for local abiotic correlates of biomass discontinuity in each lake.

\section{RESULTS}

\section{Patterns of biomass groups and discontinuities}

Our analyses revealed discontinuous biomass patterns with an overall increase in the number of regional groups of lakes with similar biomass (biomass groups) during the study period (from two in 1997 to six in 2007; Fig. 1). The biomass groups differed in biomass ranges over the years. Biomass distributions across lakes showed two discontinuities at $\sim 1.5$ and $5.5 \mathrm{~mm}^{3} \mathrm{~L}^{-1}$ that were almost consistently detected throughout the study, resulting in three primary biomass groups (Fig. 1). A third discontinuity was detected at $\sim 15 \mathrm{~mm}^{3}$ $\mathrm{L}^{-1}$ in 2003 when lakes Älgarydssjön and Hinnasjön showed extreme biomass values of $G$. semen $\left(15.4\right.$ and $17.8 \mathrm{~mm}^{3} \mathrm{~L}^{-1}$, respectively) and which gave rise to a fourth biomass group (Fig. 1). Otherwise, biomass discontinuities were less consistent. Additional discontinuities were detected within the first and second biomass groups in 1999, and more consistently between 2004 and 2007. In 2004 and 2007, the first biomass cluster $\left(<1.5 \mathrm{~mm}^{3} \mathrm{~L}^{-1}\right)$ was divided into three groups. In 2005 , 2006 , and 2007 the second biomass cluster $\left(1.5-5 \mathrm{~mm}^{3} \mathrm{~L}^{-1}\right)$ was divided into three, two, and three groups, respectively (Fig. 1).

\section{Landscape trends of biomass groups and discontinuities}

The number of G. semen-free lakes decreased significantly over time (Fig. 2). Regression analyses revealed that the increase from two to six groups of lakes with similar biomass over the study period was significant (Fig. 2), indicating an increasing regional complexity in biomass organization of $G$. semen. This increasing number of scales detected was associated with an increased detection frequency of $G$. semen across lakes (Kendall's tau $-0.631, \mathrm{P}=0.007, \mathrm{n}=11$ ). Kendall rank correlations also showed that the increased complexity in biomass group patterns, but not the decreasing number of G. semen-free lakes, were associated with regionally decreased sulfate concentrations (Kendall's tau -0.653, $\mathrm{P}=$ $0.005, \mathrm{n}=11$ ), increased alkalinity (Kendall's tau $0.484, \mathrm{P}=$ $0.04, \mathrm{n}=11$ ), and the temporal variability of water color (Kendall's tau $0.526, \mathrm{P}=0.02, \mathrm{n}=11$; Fig. 3 ). Thus, patterns of regionally increased complexity at which biomass forms across lakes were associated with regionally changing water quality characteristics and the regional occurrence patterns of G. semen. 
Fig. 2. Temporal patterns of number of resolved biomass classes of Gonyostomum semen (A) and detection of $G$. semen in lakes over time (B). Dotted lines show the least square regression lines, indicating significant temporal change.
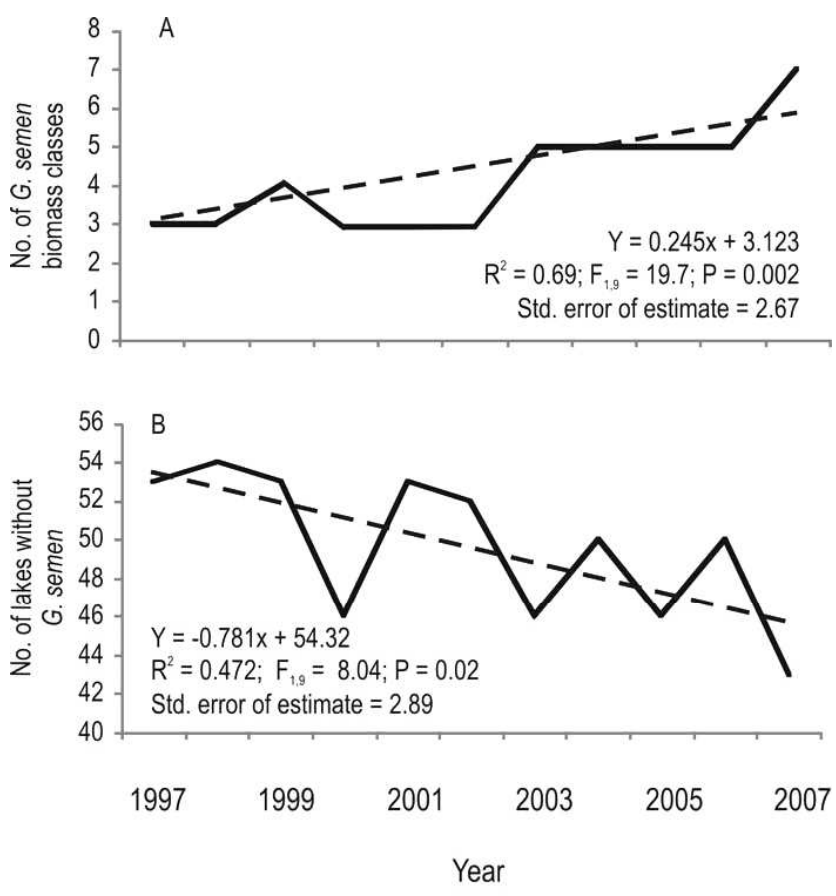

\section{Local trends of biomass groups and discontinuities}

Temporal patterns in biomass group membership of individual lakes were site specific (Table 1), indicating weak spatial congruency of biomass group membership across lakes during the study period. Biomass discontinuities in individual lakes were, with a few exceptions (Ekholmsjön, Gipsjön, Rotehogstjärnen, Gosjön, Örsjön, Sännen, Älgsjön, Storasjö), associated with the interannual variability of $G$. semen biomass development in the lakes (Table 1; Temporal trends of $G$. semen raw biomass in the lakes are in Appendix 2). Five patterns of environmental associations with the temporal changes in local biomass discontinuities were observed (Table 2): (1) no correlations with environmental variables (e.g., Ekholmsjön, Sangen, Älgsjön, Rammsjön); (2) associations with climatic, i.e., water temperature, variables (Överudssjön); (3) correlations with changes in nutrient conditions (Skärgölen, Grissjön, Sännen, Fräcksjön, Bysjön); (4) associations with changing acidity (Fagertärn, Storasjö); (5) changing water clarity (Rotehogstjärnen, Bäen, Edasjön, Skärsjön); and (6) combinations of points 2 to 5 (e.g., Hagasjön, Fjärasjön, Siggeforassjön, Tväringen, Älgarydssjön).
Fig. 3. Temporal trends of sulfate concentrations (A), alkalinity (B), and water color (C) between 1997 and 2007. Shown are the means \pm standard errors of 75 lakes. Significant temporal changes are indicated by the linear trend lines and regression details.
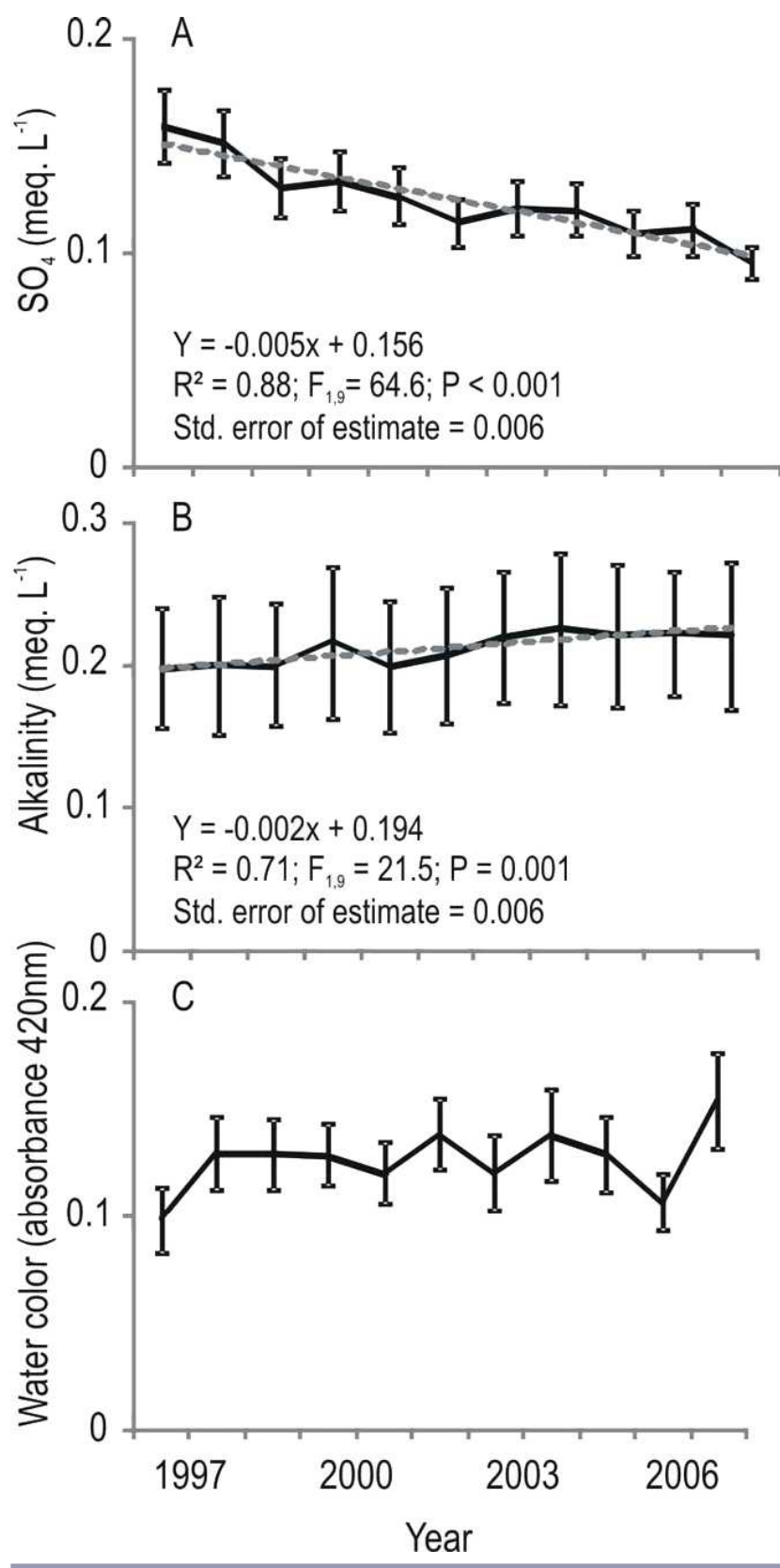

\section{DISCUSSION}

We documented that the biomass structure of an invasive nuisance species undergoes dynamic alternate states and that 
Table 1. Time series of biomass groups in lakes with the presence of Gonyostomum semen. Shown are biomass group memberships (indicated by different numbers and cell shadings) resolved by cluster and simulation analysis. The column "biomass" shows Kendall Tau correlation coefficients and significance levels (* $\mathrm{P}<0.05 ;{ }^{* *} \mathrm{P}<0.01 ;{ }^{* * *} \mathrm{P}<0.001 ; \mathrm{Ns}$, no significant correlation) from correlation analyses between time series of biomass group memberships and raw biomass data in individual lakes.

\begin{tabular}{|c|c|c|c|c|c|c|c|c|c|c|c|c|}
\hline \multirow[b]{2}{*}{ Lake } & \multicolumn{11}{|c|}{ Year } & \multirow[t]{2}{*}{ Biomass } \\
\hline & '97 & '98 & '99 & '00 & '01 & '02 & '03 & '04 & '05 & '06 & '07 & \\
\hline Ekholmssjön & & 1 & 1 & 1 & 1 & 1 & 1 & 1 & 1 & 1 & 1 & Ns \\
\hline Grissjön & 1 & & & & & & & & & & & $0.998^{\star \star \star *}$ \\
\hline Hökesjön & & & & & & & & & & & 1 & $0.998^{\star \star \star \star}$ \\
\hline Humsjön & & & & & & & & & & 1 & & $0.998^{\star \star \star \star}$ \\
\hline Lillsjön & & & & & & & 1 & & & & & $0.998^{\star \star \star}$ \\
\hline Mäsen & & & & 1 & & & & & & & & $0.998^{\star \star \star}$ \\
\hline Remmarsjön & & 1 & & & & & & & & & & $0.998^{\star \star \star *}$ \\
\hline Sangen & & & & & & & & 1 & & & & $0.998^{\star \star \star}$ \\
\hline Skärgölen & & & & & & & & & 1 & & & $0.998^{\star \star *}$ \\
\hline Spjutsjön & & 1 & & & & & & & & & & $0.998^{\star \star *}$ \\
\hline Stensjön & & & & & & & 1 & & & & & $0.998^{* * *}$ \\
\hline Tärnan & & & & & & & & & & 1 & & $0.988^{* * *}$ \\
\hline V. Rännöbodsjön & & & & & & & & & & & 1 & $0.988^{\star \star \star}$ \\
\hline Gryten & 1 & 1 & 1 & 1 & 1 & & 1 & & 1 & 1 & 1 & $0.577^{\star}$ \\
\hline Hagasjön & & & 1 & 1 & 1 & 1 & 1 & 1 & 1 & 1 & 1 & $0.577^{*}$ \\
\hline Skärsjön & & & & 1 & & & & & & & 1 & $0.973^{\star \star *}$ \\
\hline Tängersjö & & & 1 & 1 & & & & & & & & $0.973^{* * *}$ \\
\hline Ulvsjön & 1 & & & 1 & & & & & & & & $0.973^{\star \star \star}$ \\
\hline Fjärasjö & & & & & & & 1 & & 1 & & 1 & $0.943^{\star \star \star}$ \\
\hline Täftesträsket & & & & 1 & & & & & 1 & & 1 & $0.943^{\star \star *}$ \\
\hline N. Yngern & & & & 1 & 1 & 1 & & & & & 1 & $0.998^{\star \star *}$ \\
\hline Siggeforasjön & & & & & 1 & 1 & & & 1 & & 1 & $0.907^{\star \star \star}$ \\
\hline Svinarydsjön & 1 & & 1 & 1 & 1 & & & & & & & $0.907^{\star \star \star}$ \\
\hline Fräcksjön & 1 & 1 & 1 & 1 & & & & 1 & & & & $0.866^{\star \star \star}$ \\
\hline St. Lummersjön & & & & 1 & & & 1 & 1 & 1 & 1 & 1 & $0.816^{\star \star \star}$ \\
\hline Gipsjön & 1 & 1 & 1 & 1 & 1 & 1 & 1 & 1 & 1 & 1 & 3 & Ns \\
\hline Tväringen & & & & & & 1 & 2 & & & & & $0.988^{\star \star \star}$ \\
\hline Edasjön & & & & & & 2 & & 1 & 1 & & & $0.981^{\star \star \star}$ \\
\hline Harasjön & 1 & 1 & 2 & 1 & 3 & 1 & 2 & 2 & 1 & 1 & 1 & $0.460^{\star}$ \\
\hline Rotehogstjärnen & 1 & 2 & 2 & 1 & 1 & 2 & 1 & 2 & 1 & 1 & 3 & Ns \\
\hline St Skärsjön & & & & & & 1 & 1 & & 1 & 1 & 2 & $0.922^{* * *}$ \\
\hline Överudssjön & 1 & 1 & 2 & 1 & 1 & & 2 & & 1 & & 1 & $0.832^{\star \star \star}$ \\
\hline Gosjön & 2 & 2 & 3 & 2 & 3 & 2 & 2 & 2 & 2 & 1 & 4 & Ns \\
\hline Granvattnet & 1 & & 1 & 1 & 1 & 2 & 1 & 1 & 1 & 3 & 2 & $0.587^{\star}$ \\
\hline Örsjön & 1 & 1 & 2 & 1 & 2 & 2 & 2 & 3 & 1 & 1 & 3 & Ns \\
\hline Sännen & 1 & 1 & 3 & 1 & 1 & 2 & 2 & 2 & 1 & 1 & 3 & Ns \\
\hline Älgsjön & 2 & 2 & 4 & 2 & 2 & 3 & 1 & 3 & 3 & 2 & 3 & Ns \\
\hline Bäen & 1 & 2 & 3 & 1 & 1 & 1 & 3 & 2 & 3 & 2 & 3 & $0.597^{\star}$ \\
\hline Fagertärn & 1 & 1 & 4 & 2 & 1 & 1 & 1 & 2 & 2 & 1 & 2 & $0.555^{\star}$ \\
\hline Lilla Öresjön & & & & & & & 1 & 3 & & & 1 & $0.981^{\star \star \star}$ \\
\hline Bysjön & 1 & 1 & & & & 1 & 1 & 3 & 1 & 1 & 3 & $0.786^{\star \star \star}$ \\
\hline Storasjö & 2 & 2 & 3 & 3 & 3 & 3 & 1 & 3 & 3 & 1 & 5 & Ns \\
\hline Hinnasjön & & & & 1 & & & 4 & 1 & 1 & 1 & 1 & $0.882^{* * *}$ \\
\hline Rammsjön & 2 & 1 & 2 & 3 & 2 & 1 & 1 & 4 & 1 & 1 & 4 & $0.569^{*}$ \\
\hline Tomeshultagölen & 1 & 3 & 3 & 2 & 2 & 2 & 3 & 4 & 1 & 4 & 6 & $0.570^{*}$ \\
\hline Älgarydssjön & 1 & 1 & 1 & 1 & 1 & 3 & 4 & 4 & 4 & 3 & 6 & $0.653^{* \star}$ \\
\hline Tångerdasjön & & & & & & & 1 & 2 & 4 & 4 & 5 & $0.886^{\star \star \star}$ \\
\hline
\end{tabular}


Table 2. Environmental correlates of temporal changes in biomass group membership of lakes in which $G$. semen was detected. Shown are Kendall Tau correlation coefficients and significance values $(* \mathrm{P}<0.05$, unshaded cells; $* * \mathrm{P}<0.01$, light-grey shaded cells; $* * * \mathrm{P}<0.001$, darkgrey shaded cells; empty cells, not significant) of significant variables. Lakes for which no significant correlations were found are excluded from the table.

\begin{tabular}{|c|c|c|c|c|c|c|c|c|c|c|c|c|}
\hline \multirow[b]{2}{*}{ Lake } & \multicolumn{12}{|c|}{ Variables } \\
\hline & $\mathrm{Ph}$ & Alkalinity & $\mathrm{NO}_{2}+\mathrm{NO}_{3}-\mathrm{N}$ & $\mathrm{NH}_{4}-\mathrm{N}$ & Total N & $\mathrm{PO}_{4}$ & Total P & Cond. & Secchi & Color & TOC & Temp. \\
\hline Överudssjön & & & & & & & & & & & & $-0.46^{*}$ \\
\hline Grissjön & & & $0.47^{*}$ & & & & & & & & & \\
\hline Skärgölen & & & & & & $0.57 *$ & & & & & & \\
\hline Sännen & & & & & & $0.49 *$ & & & & & & \\
\hline Bysjön & & & & $-0.55^{*}$ & & $0.56^{*}$ & & & & & & \\
\hline Fräcksjön & & & & & & & & $0.50^{*}$ & & & & \\
\hline Harasjön & & & & & & & & $-0.54 *$ & & & & \\
\hline Fagertärn & $0.51^{*}$ & & & & & & & & & & & \\
\hline Storasjö & $-0.46^{*}$ & & & & & & & & & & & \\
\hline Rotehogstjärnen & & & & & & & & & $-0.69 * *$ & $0.51^{*}$ & & \\
\hline Bäen & & & & & & & & & $-0.53^{*}$ & & & \\
\hline Edasjön & & & & & & & & & & & $-0.58^{*}$ & \\
\hline Skärsjön & & & & & & & & & & & $0.48 *$ & \\
\hline Hagasjön & & $0.57^{*}$ & & & $-0.58^{*}$ & & & $-0.59 *$ & & & & \\
\hline Tängersjö & & $0.56^{*}$ & & & & & & & $0.57^{*}$ & & & $-0.57 *$ \\
\hline Fjärasjö & $-0.55^{*}$ & $-0.55^{*}$ & & & & & & $-0.55^{*}$ & $-0.51 *$ & $0.55^{*}$ & & \\
\hline Siggeforasjön & & $-0.52^{*}$ & & & & & & $-0.46^{*}$ & $-0.54 *$ & $0.51^{*}$ & $0.59 * *$ & \\
\hline Svinarydsjön & $0.66^{* *}$ & & & & $-0.51^{*}$ & & & & & & & \\
\hline St. Lummersjön & & $-0.72 * *$ & & $0.73 * *$ & & & & $-0.75 * * *$ & & & & \\
\hline Tväringen & $0.59 *$ & & $0.49 *$ & & & & & & & & & $0.47 *$ \\
\hline St Skärsjön & & & & & & $0.73 * *$ & & $-0.61 * *$ & $-0.71 * *$ & & & \\
\hline Örsjön & & & & & & & & $-0.57^{*}$ & $-0.61 * *$ & & & \\
\hline Lilla Öresjön & $0.46^{*}$ & $0.53 *$ & & & & & & & & & & $0.59^{*}$ \\
\hline Hinnasjön & & & & $0.46^{*}$ & & & $0.49 *$ & & $-0.61 * *$ & & & \\
\hline Älgarydssjön & & & & & & & $0.47 *$ & & $-0.74^{* * * *}$ & $0.74 * *$ & $0.65^{* *}$ & \\
\hline Tångerdasjön & & & $0.53 *$ & & & & & $-0.48 *$ & & $0.50 *$ & & \\
\hline
\end{tabular}

Abbreviations: TOC, total organic carbon; Cond., electrical conductivity; Color, water color (absorbance); Secchi, Secchi disk transparency; Temp., water temperature. Note: electrical conductivity is a measure of total dissolved ions in the water and can serve as a surrogate of micronutrient availability. 
the ecological factors mediating this discontinuous organization vary with the scale of observation (local vs. regional). Identifying the scale-specific organization of ecological systems, including the factors that create discontinuities in space and time, are requisite for a processbased understanding of ecological dynamics (Gunderson and Holling 2002, Allen and Holling 2008). Understanding scalespecific patterns also has clear management implications because system resilience in response to environmental stress can be more accurately assessed (Peterson et al. 1998, Angeler et al. 2011). Eradication of invasive nuisance species has proven elusive, leaving invasion and conservation biologists in a struggle to understand why invasive species are so difficult to manage. A relatively simple, ecologically integrative measure (biomass structure) and a complex adaptive systems approach to characterize the dynamics of the nuisance flagellate $G$. semen at local and regional scales, can provide insight into the process of biological invasions. Our study focuses on $G$. semen and boreal lakes as models of invasions, and suggests that similar research in other aquatic and terrestrial environments is warranted to test for generalities of the patterns we documented.

The discontinuous dynamics of local and regional biomass structure of $G$. semen raise questions about the factors that govern these patterns. Holling (1992) proposed that discontinuously distributed environmental variables of inherently different speeds entrain processes to create groups of species with similar attributes within communities. Holling's theory has since found support in other complex system types, including cities and economies (Garmestani et al. 2009), and in the organization of biomass of invasive species (this study). Allen et al. (2006) have shown that processes that operate from scales of local biological interactions to biome-scale processes can cause discontinuity, and such scale-specific processes may help explain the observed patterns of biomass dynamics at regional and local scales.

\section{Regional patterns}

The number of biomass groups increased over the study period, indicative of an increased complexity in $G$. semen biomass across lakes. This increased complexity was associated with an increased detection frequency of $G$. semen. The organization of biomass groups may track closely the invasion history of $G$. semen across the landscape because the regional variability in local growth may increase with an increased occupancy of habitats. The existence of more biomass groups may therefore be due simply to more sites being occupied by $G$. semen and the biomass development differing between these sites. However, our data show that there is neither a linear relationship between the distribution of $G$. semen and the variability of its biomass ranges over the study years (Fig. 1). This suggests that although distributional patterns of $G$. semen may be an appropriate proxy explaining the emergence of regionally discontinuous biomass structure, other processes may influence patterns of dynamic thresholds at the regional scale.

Patterns of increased complexity were also correlated with changes in the abiotic environment. Boreal lakes are currently recovering from anthropogenic acidification but are also affected by other forms of broad-scale environmental change, including global warming (e.g., Johnson and Angeler 2010). Environmental change is manifested in regionally reduced sulfate concentration and increased water color (Erlandsson et al. 2008, Angeler and Johnson 2012). The observed correlation of biomass groups with sulfate, alkalinity, and water color suggests that the regional biomass structure of $G$. semen captures the imprint of broad-scale environmental change. Our findings support hypotheses that emphasize slower, regional-scale processes for creating discontinuity in biomass formation (Allen et al. 2006), and suggest that mutually dependent broad-scale environmental change and invasion history may be associated with the increased regional complexity of $G$. semen biomass groupings.

The increased complexity of biomass group patterns at the landscape scale has implications for conservation biogeography. The increased number of biomass groups can be interpreted as an emergence of scales, which do not emerge in isolation but represent strong interaction between $G$. semen and its environment. This suggests that the presence of $G$. semen in the boreal lake landscape, and its potential to develop bloom proportions, is reinforced by processes that act within or between these scales, indicative of cross-scale resilience (Peterson et al. 1998). Cross-scale resilience is based, in part, on the notion that redundancies within and across scales helps maintain overall structure and function within a system, despite impact at individual scales. Our findings suggest that the identification and manipulation of the sets of environmental and biotic variables that contribute to this crossscale reinforcement may be increasingly difficult. Not only could G. semen resist local management efforts but also more generally different forms of natural or anthropogenic disturbances. Thus, the cross-scale resilience can be useful for explaining the apparent ecological success of $G$. semen at the landscape scale and shed light on the constraints to regional conservation planning.

\section{Local patterns}

Despite the existence of discontinuous biomass organization at the local scale, we observed that individual lakes were not conservative in their biomass group membership and that these patterns were idiosyncratic over the study period. The group membership patterns were largely correlated with the dynamics of raw biomass, suggesting that the magnitudes of bloom events between years can indeed lead to discontinuities. However, there were also exceptions with a few lakes not showing significant correlations, providing mixed support of our hypothesis. This may be due to a constant biomass group 
membership of selected lakes (Ekholmsjön, Gipsjön; Table 1), leading to a weak concordance between their membership ranks and the more dynamic patterns of raw biomass. For other lakes (Rotehogstjärnen, Gosjön, Örsjön, Sännen, Älgsjön, Storasjö), the lack of correlation can be explained by the way we have quantified group membership. We calculated membership of individual lakes to regional biomass groups based on the determination of discontinuities for individual years. Biomass ranges varied between years, leading to different membership status of lakes despite similar biomass ranges in individual years (Fig. 1). The resulting lack of correlation can therefore be explained by a mismatch between raw biomass magnitudes and biomass group membership assignments for these lakes. Although a standardization of biomass group membership on the basis of defined biomass ranges would have avoided such a mismatch, the inconsistent placements of discontinuities in the data sets across the different years neither allowed for making such standardization nor was it the aim of this study. The current design permitted for direct comparisons between local and regional scale dynamics, and we are confident that appropriate inference can be made about the factors that mediate discontinuous organization between these scales.

Patterns of local biomass group membership were associated with different sets of environmental variables, indicative of lake-specific responses to changes in acidity and nutrient conditions, water clarity, and temperature. Some of these variables also acted as regional correlates of biomass discontinuity. Their imprints at both local and regional scales suggest that they can influence biomass structure at different scale-inherent speeds. The following arguments highlight that the processes of entrainment differ between these spatial scales. If exogenous, regional variables, such as those associated with broad-scale environmental change (recovery from acidification, climate change), lead to deterministic control of biomass groups at the local scale, we would expect regionally synchronized biomass dynamics and similar biomass group memberships across lakes over time. This was, however, not the case in our study. Furthermore, some lakes lacked a correlation between group membership and environmental variables, highlighting the importance of stochastic variables mediating biomass development of $G$. semen in boreal lakes. Weak environmental control has also been found in other studies, although $G$. semen biomass development was not explicitly studied from a complex adaptive systems perspective (Bloch 2010). This suggests that other system-intrinsic components, such as physiological aspects of $G$. semen, recruitment rate, or interactions with other species, likely play a major role in determining the patterns of biomass development (Hansson 2000, Figueroa and Rengefors 2006), and thus discontinuities. G. semen adapts to, and forms blooms under a broad range of environmental conditions, favored by its ability for diurnal vertical migration, which allows it to optimally exploit a range of habitats (Salonen and Rosenberg 2000), and its mixotrophic character, which is important under nutrient and light limitation (Rengefors et al. 2008). Taken together, it is likely that the combination of such processes sets the constraints for biomass development at the local scale of lakes. These constraints differ among lakes within a region and are highly dynamic temporally. This supports the "community interaction hypothesis" (Allen et al. 2006), which emphasizes local stochastic and deterministic short-term processes for creating discontinuity in complex systems.

There are management consequences of the local patterns reported here. Lake managers often focus on nutrient reductions to control undesired algal blooms (Jeppesen et al. $2007 a, b$ ). Our results show that neither the transition of biomass states of $G$. semen (this study) nor the temporal changes in raw biomass (Angeler et al. 2010) are exclusively related to changes in the trophic conditions of the lakes. These inconsistent associations of biomass dynamics with trophic state variables, combined with more complex patterns of associations with other environmental and/or potentially biotic variables, suggests that interventions in the nutrient regimes of boreal brown-water lakes will not be as efficient for controlling algal blooms as in clear water lakes.

We conclude by highlighting relationships of biomass structure between local and regional scales and their broader implications for ecological theory and management. Despite having deduced local from regional discontinuity patterns, we found evidence that regional dynamics are to some extent influenced by local dynamics. This influence was manifested in the nonlinear relationship between the distribution of $G$. semen and the variability of its biomass ranges in the landscape and dynamic biomass thresholds leading to different regional discontinuity patterns over the years. This suggests that although regional biomass structure is conservative following scale-specific organization, the form of discontinuities may be modulated by local biomass structures and the resulting regional biomass group membership of lakes. This highlights that phenomena related to species invasions, and likely other ecological phenomena, cannot be fully understood if scales in complex adaptive systems are dealt with as independent entities (Levin 1992).

Responses to this article can be read online at: http://www.ecologyandsociety.org/vol17/iss2/art32/ responses/

\section{Acknowledgments:}

The authors thank the Swedish Environmental Protection Agency and the many people involved in the monitoring program. DGA and RKJ acknowledge the support of the 
WISER (Water bodies in Europe: Integrative Systems to assess Ecological status and Recovery, contract No. 226273, www. wiser.eu) and REFRESH (Adaptive Strategies to Mitigate the Impacts of Climate Change on European Freshwater Ecosystems, contract No 244121, www.refresh.ucl.ac.uk/) projects funded by the European Union under the 7th Framework Programme, Theme 6 (Environment including Climate Change). The Nebraska Cooperative Fish and Wildlife Research Unit is jointly supported by a cooperative agreement between the United States Geological Survey, the Nebraska Game and Parks Commission, the University of Nebraska-Lincoln, the United States Fish and Wildlife Service, and the Wildlife Management Institute. Any use of trade names is for descriptive purposes only and does not imply endorsement by the U.S. Government. The authors also acknowledge support from the August T. Larsson Guest Professorship Programme of the Swedish University of Agricultural Sciences, and Stina Drakare and the reviewers for helpful comments on a previous version of the manuscript.

\section{LITERATURE CITED}

Allen, C. R., E. A. Forys, and C. S. Holling. 1999. Body mass patterns predict invasions and extinctions in transforming landscapes. Ecosystems 2:114-121. http://dx.doi.org/10.1007/ $\underline{\mathrm{s} 100219900063}$

Allen, C. R., A. S. Garmestani, T. D. Havlicek, P. A. Marquet, G. D. Peterson, C. Restrepo, C. A. Stow, and B. E. Weeks. 2006. Patterns in body mass distributions: sifting among alternative hypotheses. Ecology Letters 9:630-643. http://dx.d oi.org/10.1111/j.1461-0248.2006.00902.x

Allen, C. R., L. Gunderson, and A. R. Johnson. 2005. The use of discontinuities and functional groups to assess relative resilience in complex systems. Ecosystems 8:958-966. http:// dx.doi.org/10.1007/s10021-005-0147-x

Allen, C. R., and C. S. Holling. 2008. Discontinuities in ecosystems and other complex systems. Columbia University Press, New York, New York, USA.

Allen, C. R., and C. S. Holling. 2010. Novelty, adaptive capacity, and resilience. Ecology and Society 15(3): 24. [online] URL: http://www.ecologyandsociety.org/vol15/iss3/ $\underline{\operatorname{art} 24 /}$

Angeler, D. G., S. Drakare, and R. K. Johnson. 2011. Revealing the organization of complex adaptive systems through multivariate time series modeling. Ecology and Society 16(3): 5. http://dx.doi.org/10.5751/ES-04175-160305

Angeler, D. G., and R. K. Johnson. 2012. Temporal scales and patterns of invertebrate biodiversity dynamics in boreal lakes recovering from acidification. Ecological Applications, in press. $\underline{\text { http://dx.doi.org/10.1890/11-1474.1 }}$
Angeler, D. G., C. Trigal, S. Drakare, R. K. Johnson, and W. Goedkoop. 2010. Identifying resilience mechanisms to recurrent ecosystem perturbations. Oecologia 164:231-241. http://dx.doi.org/10.1007/s00442-010-1640-2

Bloch, I. 2010. Global change impacts on phytoplankton communities in nutrient-poor lakes. Thesis. Swedish University of Agricultural Sciences, Uppsala, Sweden.

Cronberg, G., G. Lindmark, and S. Björk. 1988. Mass development of the flagellate Gonyostomum semen (Raphidophyta) in Swedish forest lakes - an effect of acidification? Hydrobiologia 161:217-236. http://dx.doi.org/1 $\underline{0.1007 / \mathrm{BF} 00044113}$

Eloranta, P., and A. Räike. 1995. Light as a factor affecting the vertical distribution of Gonyostomum semen (Ehr.) Diesing (Raphidophyceae) in lakes. Aqua Fennica 25:15-22.

Erlandsson, M., I. Buffam, J. Fölster, H. Laudon, J. Temnerud, G. A. Weyhenmeyer, and K. Bishop. 2008. Thirty-five years of synchrony in the organic matter concentrations of Swedish rivers explained by variation in flow and sulfate. Global Change Biology 14:1191-1198. http://dx.doi.org/10.1111/j.13 65-2486.2008.01551.x

Figueroa, R., and K. Rengefors. 2006. Life cycle and sexuality of the freshwater raphidophyte Gonyostomum semen (Raphidophyceae). Journal of Phycology 42:859-871. http://d x.doi.org/10.1111/j.1529-8817.2006.00240.x

Findlay, D. L., J. J. Paterson, L. L. Hendzel, and H. J. Kling. 2005. Factors influencing Gonyostomum semen blooms in a small boreal reservoir lake. Hydrobiologia 533:243-252. http ://dx.doi.org/10.1007/s10750-004-2962-Z

Garmestani, A. S., C. R. Allen, and L. Gunderson. 2009. Panarchy: discontinuities reveal similarities in the dynamic system structure of ecological and social systems. Ecology and Society 14(1): 15. [online] URL: http://www.ecologyand society.org/vol14/iss 1/art15

Gunderson, L. H., and C. S. Holling. 2002. Panarchy: understanding transformations in human and natural systems. Island Press, Washington, D.C., USA.

Hansson, L. A. 2000. Synergistic effects of food chain dynamics and induced behavioral responses in aquatic ecosystems. Ecology 81:842-851. http://dx.doi.org/10.1890/0 012-9658(2000)081[0842:SEOFCD]2.0.CO;2

Holling, C. S. 1992. Cross-scale morphology, geometry, and dynamics of ecosystems. Ecological Monographs 62:447-502. http://dx.doi.org/10.2307/2937313

Hongve, D., O. Lovstad, and K. Bjorndalen. 1988. Gonyostomum semen - a new nuisance to bathers in Norwegian lakes. Verhandlungen der internationalen Vereinigung für theoretische und angewandte Limnologie $23: 430-434$. 
Jeppesen, E., M. Meerhoff, B. A. Jacobsen, R. S. Hansen, M. Søndergaard, J. P. Jensen, T. L. Lauridsen, N. Mazzeo, and C. W. C. Branco. 2007a. Restoration of shallow lakes by nutrient control and biomanipulation - the successful strategy varies with lake size and climate. Hydrobiologia 581:269-285. http://dx.doi.org/10.1007/s10750-006-0507-3

Jeppesen, E., M. Søndergaard, M. Meerhoff, T. L. Lauridsen, and J. P. Jensen. 2007b. Shallow lake restoration by nutrient loading reduction - some recent findings and challenges ahead. Hydrobiologia 584:239-252. http://dx.doi.org/10.1007/ $\underline{\text { s10750-007-0596-7 }}$

Johnson, R. K. 1999. Regional representativeness of Swedish reference lakes. Environmental Management 23:115-124. htt p://dx.doi.org/10.1007/s002679900172

Johnson, R. K., and D. G. Angeler. 2010. Tracing recovery under changing climate: response of phytoplankton and invertebrate assemblages to decreased acidification. Journal of the North American Benthological Society 29:1472-1490. http://dx.doi.org/10.1899/09-171.1

Kendall, M. 1938. A new measure of rank correlation. Biometrika 30:81-89.

Le Cohu, P. R., J. Guitard, N. Comoy, and J. Brabet. 1989. Gonyostomum semen a potential nuisance in large French reservoirs? The case of the Pareloup lake. Archiv für Hydrobiologie 117:225-36.

Levin, S. A. 1992. The problem of pattern and scale in ecology. Ecology 73:1943-1967. http://dx.doi.org/10.2307/1941447

MacDougall, A. S., and R. Turkington. 2005. Are invasive species the drivers or passengers of change in degraded ecosystems? Ecology 86:42-55. http://dx.doi.org/10.1890/04$\underline{0669}$

Millennium Ecosystem Assessment. 2005. Ecosystems and human well-being: current state and trends. Island Press, Washington, D.C., USA. [online] URL: http://www.maweb.org/ en/Condition.aspx

Müllerová, J., P. Pyšek, V. Jarošik, and J. Pergl. 2005. Aerial photographs as a tool for assessing the regional dynamics of the invasive plant species Heracleum mantegazzianum. Journal of Applied Ecology 42:1042-1053. http://dx.doi.org/1 $\underline{0.1111 / j .1365-2664.2005 .01092 . x}$

Olrik, K. P., P. Blomqvist, P. Brettum, G. Cronberg, and P. Eloranta. 1989. Methods for quantitative assessment of phytoplankton in freshwaters, part I. Swedish Environmental Protection Agency, Stockholm, Sweden.

Pattison R. R., G. Goldstein, and A. Ares. 1998. Growth, biomass allocation and photosynthesis of invasive and native Hawaiian rainforest species. Oecologia 117:449-459. http://d $\underline{\text { x.doi.org/10.1007/s004420050680 }}$
Peterson, G. D., C. R. Allen, and C. S. Holling. 1998. Ecological resilience, biodiversity, and scale. Ecosystems 1:6-18. http://dx.doi.org/10.1007/s100219900002

Pickhardt, P. C., C. L. Folt, C. Y. Chen, B. Klaue, and J. D. Blum. 2002. Algal blooms reduce the uptake of toxic methylmercury in freshwater food webs. Proceedings of the National Academy of Sciences USA 99:4419-4423. http://dx.d oi.org/10.1073/pnas.072531099

Rabalais, N. N., R. E. Turner, R. J. Díaz, and D. Justić. 2009. Global change and eutrophication of coastal waters. ICES Journal of Marine Science 66:1528-1537. http://dx.doi.org/10 .1093/icesjms/fsp047

Rengefors, K., C. Pålsson, L. A. Hansson, and L. Heiberg. 2008. Cell lysis of competitors and osmotrophy enhance growth of the bloom-forming alga Gonyostomum semen. Aquatic Microbial Ecology 51:87-96. http://dx.doi.org/10.3354/ $\underline{\text { ame } 01176}$

Restrepo, C., L. M. Renjifo, and P. Marples. 1997. Frugivorous birds in fragmented neotropical montane forests: landscape pattern and body mass distribution. Pages 171-189 in W. F. Laurance, R. O. Bierregaard, and C. Moritz, editors. Tropical forest remnants: ecology, management and conservation of fragmented communities. University of Chicago Press, Chicago, Illinois, USA.

Richardson, L. L. 1996. Remote sensing of algal bloom dynamics. BioScience 46:492-501. http://dx.doi.org/10.2307/ $\underline{1312927}$

Rondel, C., R. Arfi, D. Corbin, F. Le Bihan, E. H. Ndour, and X. Lazzaro. 2008. A cyanobacterial bloom prevents fish trophic cascades. Freshwater Biology 53:637-651. http://dx.d oi.org/10.1111/j.1365-2427.2007.01894.X

Salonen, K., and M. Rosenberg. 2000. Advantages from diel vertical migration can explain the dominance of Gonyostomum semen (Raphidophyceae) in a small, steeplystratified humic lake. Journal of Plankton Research 22:1841-1853. http://dx.doi.org/10.1093/plankt/22.10.1841

SAS Institute Inc. 1999. SAS/STAT user's guide, Version 8, vol. 2. SAS Institute, Cary, North Carolina, USA.

Scheffer, M. 2004. Ecology of shallow lakes. Kluwer Academic, Dordrecht, The Netherlands.

Silverman, B. W. 1981 Using kernel density estimates to investigate multimodality. Journal of the Royal Statistical Society 43:97-99.

Stow, C., C. R. Allen, and A. S. Garmestani. 2007. Evaluating discontinuities in complex systems: toward quantitative measures of resilience. Ecology and Society 12(1): 26. [online] URL: http://www.ecologyandsociety.org/vol12/iss1/art26/ 
Trigal, C., W. Goedkoop, and R. K. Johnson. 2011. Changes in phytoplankton, benthic invertebrate and fish assemblages of boreal lakes following invasion by Gonyostomum semen. Freshwater Biology 56:1937-1948. http://dx.doi.org/10.1111/ j.1365-2427.2011.02615.x

Vilhena, L. C., I. Hillmer, and J. Imberger. 2010. The role of climate change in the occurrence of algal blooms: Lake Burragorang, Australia. Limnology and Oceanography 55:1188-1200. http://dx.doi.org/10.4319/10.2010.55.3.1188

Wilander, A., R. K. Johnson, and W. Goedkoop. 2003. Riksinventering 2000. En synoptisk studie av vattenkemi och bottenfauna i svenska sjöar och vattendrag. Institutionen för Miljöanalys, Uppsala, Sweden. 


\section{Appendix 1}

\section{Insight on invasions and resilience derived from spatiotemporal discontinuities of}

\section{biomass at local and regional scales}

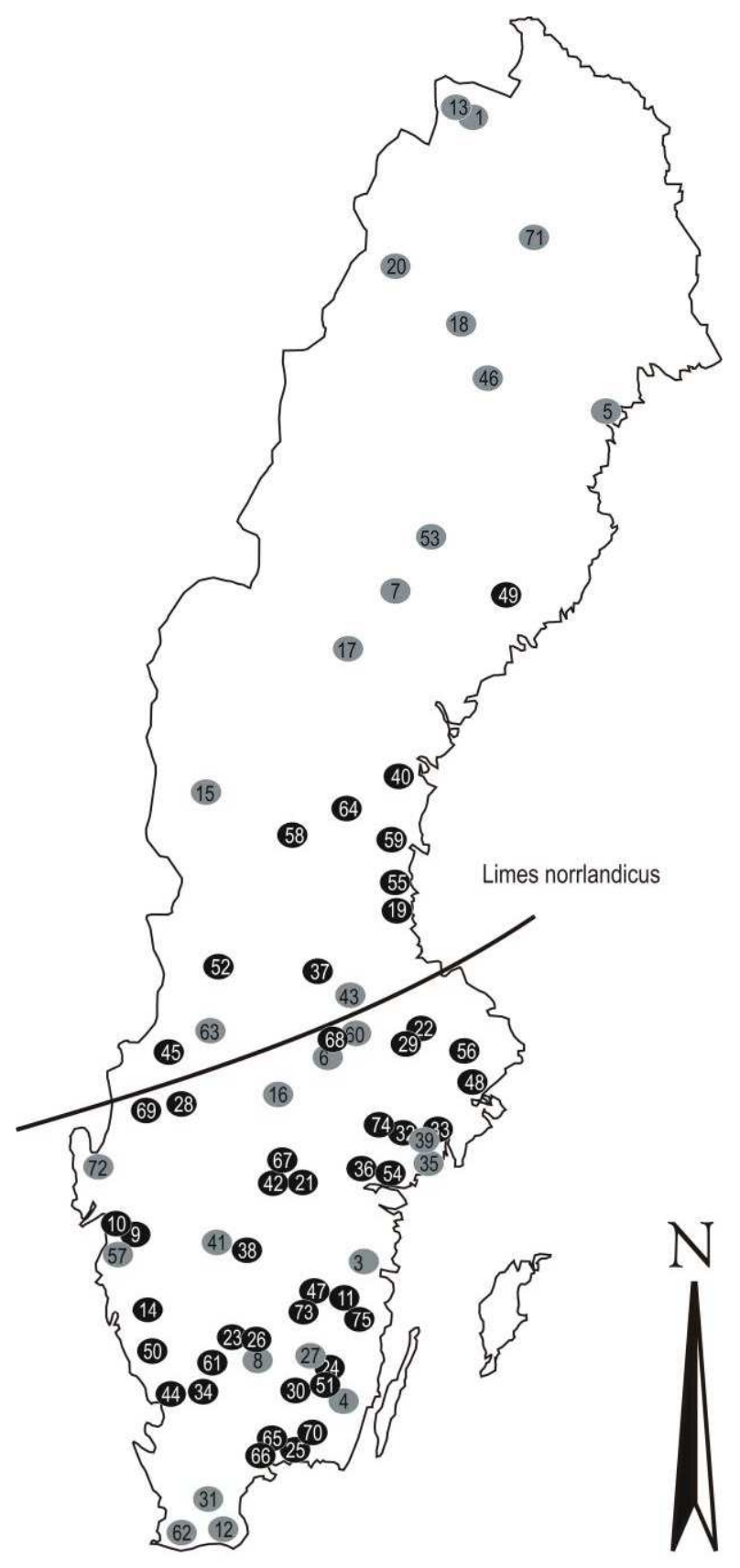

Map of Sweden showing location of study lakes. Grey symbols show lakes where Gonyostomum semen was not detected during the study period. Black symbols indicate sites where G. semen was present at least once between 1997 and 2007. 1, Abiskojaure; 2, Allgjuttern, 3, Björken; 4, Brunnsjön; 5, Brännträsket; 6, Dagarn; 7, Degervattnet; 8, Fiolen; 9, Fräcksjön; 10, Granvattnet; 11, Hökesjön; 12, Krageholmssjön; 13, Latnajaure; 14, Lilla Örjesjön; 15, Fjätsjön Övre; 16, Limmingsjön; 17, Fyrsjön; 18, Louvvajaure; 19, Gosjön; 20, Njalakjaure; 21, Grissjön; 22, 
Siggeforasjön; 23, Hagasjön; 24, Storasjö; 25, Svinarydsjön; 26, Älgarydssjön; 27, Hjärtasjön; 28, Överrudssjön; 29, Ekholmssjön; 30, Hinnasjön; 31, Krankesjön; 32, Lillsjön; 33, N. Yngern; 34, Rammsjön; 35, Rundbosjön; 36, Skärgölen; 37, Spjutsjön; 38, St. Lummersjön; 39, Stora

Envättern; 40, V. Rännöbodsjön; 41, Ymsen, 42, Humsjön; 43, Hällsjön; 44, St. Skärsjön; 45, Ulvsjön; 46, Vuolgamjaure; 47, Fjärasjö; 48, Tärnan, 49, Remmarsjön; 50, Skärsjön; 51,

Tomeshultagölen; 52, Gipsjön; 53, Stor-Arasjön; 54, Gryten; 55, Täfteträsket; 56, Edasjön; 57, Härsvatten; 58, Sangen; 59, Stensjön; 60, Övre Skärsjön; 61, Harasjön; 62, Havgårdssjön; 63, Översjön; 64, Tväringen; 65, Örjsön; 66, Bäen; 67, Fagertärn; 68, Mäsen; 69, Bysjön; 70, Sännen; 71, Jutsajaure; 72, Rotehogstjärnen; 73, Tångerdasjön; 74, Älgsjön; 75, Tångersjö. 


\section{Appendix 2}

\section{Insight on invasions and resilience derived from spatiotemporal discontinuities of}

\section{biomass at local and regional scales}

Temporal trends of raw biomass (expressed as biovolume) of G. semen in lakes where the alga was detected at least once over the study period (1997-2007).

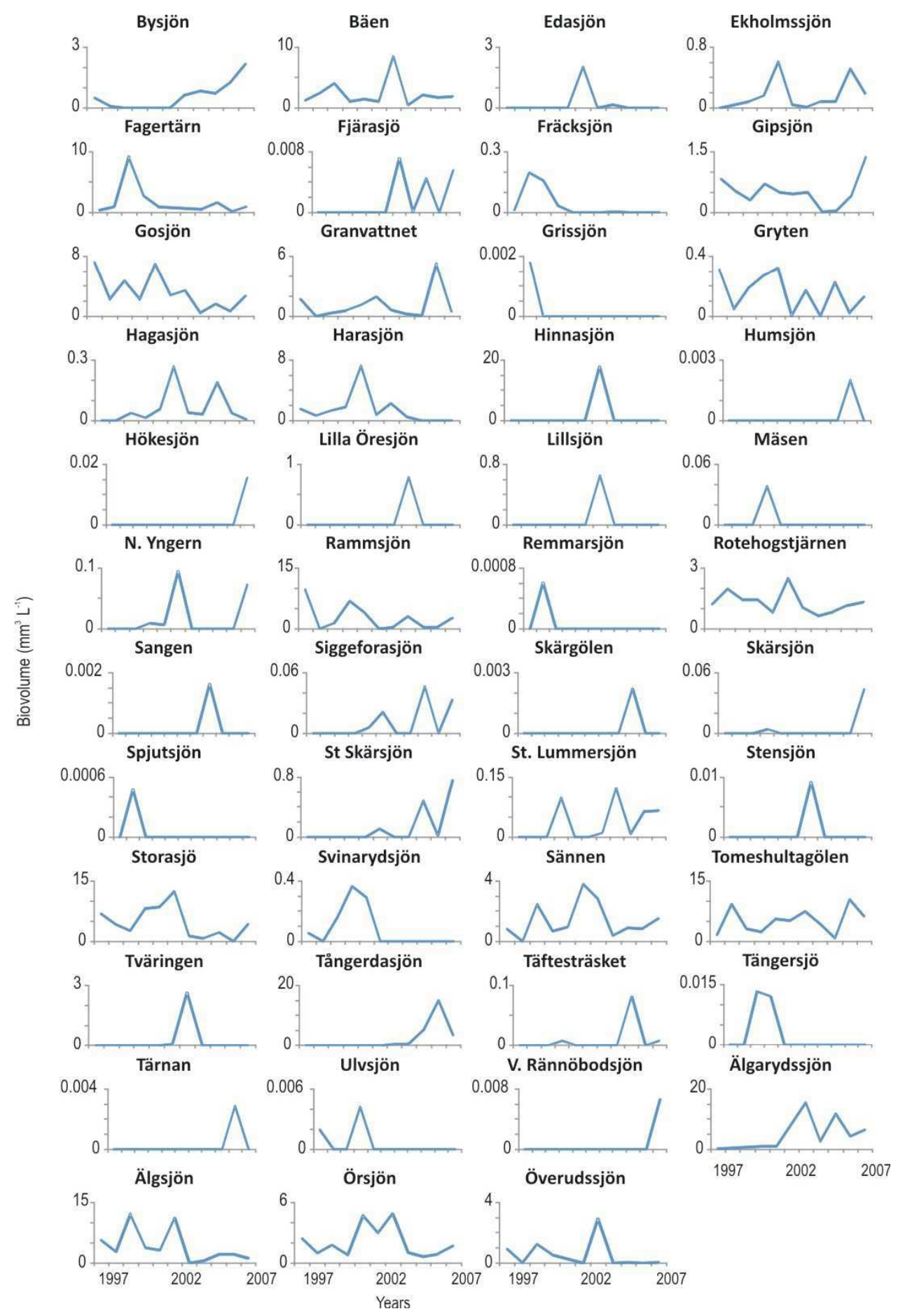

